\title{
PENGELOLAAN IKAN BATAK (Neolissochilus thienemanni, Ahl1933) DI PERAIRAN UMUM DARATAN, DANAU TOBA, PROVINSI SUMATERA UTARA
}

\section{BATAK FISHES (Neolissochilus thienemanni, Ahl 1933) MANAGEMENT IN INLAND WATERS,TOBA LAKE, NORTH SUMATERA PROVINCE}

\author{
Basuki Rachmad ${ }^{\#}$ Emalia Sihombing, dan Nunung Sabariyah \\ Sekolah Tinggi Perikanan \\ Jl. AUP Pasar Minggu-Jakarta Selatan 12520 \\ E-mail: emaliasihombing17@gmail.com
}

(Diterima: 17 Oktober 2019; Diterima setelah perbaikan: 20 November 2019; Disetujui: 20 November 2019)

\begin{abstract}
ABSTRAK
Ikan batak (Neolissochilus thienemanni, Ahl 1933) merupakan ikan endemik Sumatera Utara khususnya Danau Toba, Hulu Sungai Asahan, dan telah masuk dalam kategori terancam punah (vulnerable) berdasarkan Fishbase tahun 2014 sudah sangat sulit untuk ditemukan di habitat alaminya. Ikan ini termasuk famili Cyprinidae yang merupakan ikan omnivoradanhidup di sungai beraliran deras. Tujuan penelitian untuk mengetahui aspek biologi, aspek perikanan, kualitas perairan serta upaya pengelolaan ikan batak. Lokasi penelitian adalah tiga kabupaten di Provinsi Sumatera Utara pada bulan Agustus hingga Oktober 2018. Penelitian ini dilakukan dengan menggunakan metode sensus. Hasil pengamatanditemukan 38 ekor ikan batak (25 ekor jantan; 13 ekor betina) dengan ukuran panjang berkisar $16 \mathrm{s.d} 41.9 \mathrm{~cm}$ dan berat berkisar 73 s.d 392 gram. Pertumbuhannya bersifat allometrik negatif. Sex ratio menunjukkan tidak ada perbedaan nyata antara jantan dan betina $(1: 0,52)$. Di dominansi adalah TKG III dengan jumlah 16 ekor (11 ekor jantan ; 5 ekor betina). Nilai $\mathrm{Lc}=$ jantan $26,00 \mathrm{~cm}$; betina $=25,04 \mathrm{~cm}$, dan $\mathrm{Lm}=$ jantan $25,89 \mathrm{~cm}$; betina $23,29 \mathrm{~cm}$. Hubungan antara Lc dan Lm menunjukkan bahwa ikan yang tertangkap sudah matang gonad terlebih dahulu. Kebiasaan makan ikan didominasi oleh biji-bijian $37 \%$, plankton $25 \%$, siput $22 \%$ dan serangga $16 \%$. Berdasarkan hasil penelitian, belum adanya pengelolaan yang berkelanjutan mengenai ikan batak, baik dari pemerintah maupun masyarakat lokal. Jika dalam waktu panjang penangkapan ikan endemik terus meningkat, maka akan mengakibatkan hilangnya populasi sementara ikan batak dan perubahan rantai makanan.
\end{abstract}

KATA KUNCI: Ikan batak; aspek biologi; aspek perikanan; Danau Toba

\begin{abstract}
Batak fish (Neolissochilus thienemanni, Ahl 1933) is an endemic fish in North Sumatra, especially Lake Toba, upstream of the Asahan River, and is included in the vulnerable category based on the IUCN Red List and has been very difficult to find in its natural habitat. Batak fishes (Neolissochilus thienemanni)one of Cyprinidae families one of the omnivorous fish that lives in fast flowing rivers. The purpose of research is to determine biology aspects, fisheries aspect, water qualities and management efforts conducted at three districts in August to October 2018. The method used is sensus. The results found 38 batak fish (25 male fish; 13 female fish) with a length ranging from 16 to $41,9 \mathrm{~cm}$ and weighing in at 73 to 392 grams. Temporary research result showed that longht-weight relationships are allometrically negative. Sex ratio shows a balance value. GMR is the dominant GMR III with 16 fish (11 male fish; 5 female fish). Lc $26,00 \mathrm{~cm}$ male; $25,04 \mathrm{~cm}$ female and $\mathrm{Lm} 25,89 \mathrm{~cm}$ male;23,29 cm female. The relationship between $\mathrm{Lc}$ and $\mathrm{Lm}$ shows the fish caught has gonad ripe first. Feeding habits of it dominated by grains $37 \%$, plankton $25 \%$, snails $22 \%$ and insects $16 \%$.Based on the results of the study, there is no sustainable management of batak fish, both from the government and local communities. It will result the temporary loss of batak fish population and change the food chain.
\end{abstract}

KEYWORDS: Batak fish; biology aspects; fisheries aspect; Toba Lake

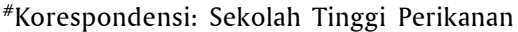

E-mail: emaliasihombing17@gmail.com 


\section{PENDAHULUAN}

Indonesia merupakan negara yang memiliki kekayaan biodiversitas sangat tinggi (Nurudin et al., 2013) sehingga dimasukkan kedalam daftar negara mega-biodiversitas, setelah Brazil (Wargasasmita, 2002), dan diperkirakan 8.500 jenis ikan hidup di perairan Indonesia (Imelda et al., 2016). Dari jumlah tersebut 1.300 jenis menempati perairan air tawar (Suwelu, 2005). Keberadaan habitat perairan darat merupakan penunjang kehidupan serta keanekaragaman ikan. Variasi keragaman ikan sangat banyak termasuk Cypinidaeyang telah dikenal sebagai penghuni utama beberapa sungai di Sumatera, akan tetapi hanya beberapa jenis saja yang dikenal dan dimanfaatkan untuk kegiatan perikanan tangkap, perikanan budidaya maupun pariwisata secara luas oleh masyarakat (Fithra, 2010).

Provinsi Sumatera Utara terletak pada posisi $01^{\circ}-$ $4^{\circ} \mathrm{LU}$ dan $098^{\circ}-100^{\circ} \mathrm{BT}$ dengan luasan $72.981,23$ ha yang merupakan pulau barat Indonesia dan memiliki kekayaan sumberdaya alam yang melimpah (Wargasasmita, 2002), baik perikanan tangkap maupun perikanan budidaya dengan $23 \%$ jenis ikan air tawar telah tercatat sebagai penghuni ekosistem air tawar di Sumatra (Fithra, 2010), 58 jenis $(9,8 \%)$ diantaranya termasuk ikan endemik (Wargasasmita, 2002), dengan keanekaragaman jenis yang relatif rendah akan tetapi memiliki kontribusi penting untuk masyarakat (Wargasasmita,2002).

Perairan Umum Daratan (PUD) adalah perairan tawar yang memiliki ruang lingkup lebih kecil dibandingkan perairan laut (Partomo et al., 2011) Perairan umum daratan meliputi danau, sungai, situ, waduk dan rawa yang biasa disebut perairan menggenang sebagai habitat ikan air tawar (Wiadnyana et al., 2015). Pada perairan darat terdapat fitoplankton yang merupakan organisme mikro yang melayang dalam air kemudian bergerak secara pasif tergantung pada angin dan arus (Alianto, 2017). Menurut PP. No. 38 Tahun 2011 tentang sungai didefinisikan bahwa, sungai adalah alur atau wadah alami dan /atau buatan berupa jaringan pengaliran air beserta air di dalamnya, mulai dari hulu sampai muara dengan dibatasi kanan dan kiri oleh garis sempadan (Lensun dan Tumembouw, 2013). Terdapat 20 sungai yang mengalir di Sumatera Utara baik untuk irigasi, air minum, pertanian maupun industri (Nasution dan Alexander, 2017). Sungai merupakan habitat perairan lahan gambut yang penting bagi kehidupan fauna salah satunya adalah ikan (Nurudin et al., 2013), namun pemanfaatan sungai yang melebihi kapastitas dapat merubah struktur alami maupun antropogenik sehingga dibutuhkan pelestarian agar fungsi sungai dapat berjalan (Fiesca et al., 2014).
Ikan batak (Neolissochilus thienemanni,Ahl 1933) merupakan ikan endemik Sumatera Utara khususnya di Danau Toba, Hulu Sungai Asahan, dan telah masuk dalam kategori terancam punah (Vulnerable) berdasarkan IUCN Red List dan sudah sangat sulit untuk ditemukan di habitat alaminya (Simanjuntak, 2012;Barus, 2016). dengan populasi nya kian lama kian menurun dikarenakan beberapa faktor seperti lenyapnya habitat, pemanasan global (Wargasasmita, 2005), aktifitas penangkapan yang berlebihan, serta adanya desakan lingkungan tempat ikan-ikan ini berkembang biak menjadi rusak. Ikan batak atau lebih populer disebut "ihan batak" yang terdisribusi di air deras dan dijumpai di upacara - upacara adat sebagai syarat terlaksananya kegiatan adat tersebut (Zairin et al., 2005). Ikan ini biasa hidup di sungai yang berpasir maupun berbatu, dengan suhu yang relative rendah $\left(16-26{ }^{\circ} \mathrm{C}\right)$, berair jernih, $\mathrm{pH}$ netral dengan stabilitas perairan yang baik serta memiliki kelimpahan jenis individu plankton yang rendah didominasi oleh chlorophyceae. Berdasarkan sifat fisika, kimia dan biologi perairan habitat ikan batak termasuk kedalam oligotropik (Simangunsong et al., 2015), dimana keberadaan plankton sangat sedikit yang menggambarkan tingkat produktivitas perairan (Sagala, 2012; Muthmainnah et al., 2012). Ikan batak diperkirakan memijah bulan Januari-Februari atau pada musim penghujan (Kristanto et al., 2007).

\section{BAHAN DAN METODE}

Penelitian ini telah dilaksanakan pada tanggal 20 Agustus sampai dengan 20 Oktober 2018, di 3 sungai yaitu Aek Sirambe Nauli Kabupaten Toba Samosir, Aek Sarulla Kabupaten Tapanuli Utara dan Lae Renun Kabupaten Dairi.

Metode penelitian yang digunakan adalah metode sensus. Sampel sebanyak 38 ekor (25 ekor jantan; 13 ekor betina). Panjang ikan menggunakan alat ukur penggaris plastic Panjang $30 \mathrm{~m}$ dengan ketelitian 1 mm sedangkan alat ukur berat dengan menggunakan timbangan digital dengan ketelitian 0,001 gr. Analisis meliputi hubungan panjang-berat; sex ratio (perbandingan jenis kelamin); TKG (Tingkat Kematangan Gonad); Ukuran pertama kali tertangkap (Lc); ukuran pertama kali matang gonad (Lm) dan kebiasaan makan ikan. Analisi hubungan panjang berat digunakan persamaan Tech (1968) dalam Suryandari dan Krismono (2011):

$$
\mathrm{W}=\mathrm{a} \mathrm{L}^{\mathrm{b}}
$$

Keterangan:

$\mathrm{W}=$ Berat ikan $(\mathrm{gr})$

$\mathrm{L}=$ Panjang ikan $(\mathrm{cm})$ 
$\mathrm{a}=$ intercept (perpotongan antara garis regresi y)

$\mathrm{b}=$ slope (tangen sudut kemiringan)

Analisis nisbah kelamin (sex ratio) untuk mengetahui hubungan jantan-betina dari suatu populasi ikan maupun pemijahannya maka pengamatan mengenai nisbah kelamin (sex ratio) ikan yang diteliti merupakan salah satu faktor yang amat penting. Selanjutnya, untuk mempertahankan kelestarian ikan yang diteliti diharapkan perbandingan ikan jantan dan betina seimbang ( $1: 1)$. Menurut Romimohtarto (2001) dalam Kembaren dan Ernawati (2011). Nisbah kelamin jantan dan betina dapat diperoleh 2 dengan menggunakan uji Chi-square $\left(\mathrm{X}^{2}\right)$ yaitu :

$$
\chi^{2}=\frac{\delta-E i}{E i}
$$

Keterangan:

$\mathrm{X}^{2}=$ Chi-square

$\ddot{a}=$ frekuensi ikan jantan dan betina yang diamati

$\mathrm{Ei}=$ frekuensi ikan yang diharapkan dengan hipotesis(1:1)

Ukuran pertama kali tertangkap dilakukan dengan membuat grafik hubungan antara panjang ikan (sumbu $\mathrm{x}$ ) dengan jumlah ikan (sumbu Y) sehingga diperoleh kurva S. Nilai length at first capture yaitu panjang pada $50 \%$ pertama kali tertangkap dapat dihitung dengan menggunakan rumus (Prihatiningsih \& Hartati, 2012) :

$$
\mathrm{SLc}=\frac{1}{1+\exp (\mathrm{aL}+\mathrm{b})}
$$

\section{Keterangan:}

$\mathrm{SL}_{\mathrm{c}}=$ ikan dengan panjang L yang tertangkap dibagi dengan ikan dengan panjang $L$ yang lolos dari alat tangkap

$\mathrm{a} \& \mathrm{~b}=$ parameter kurva $(\mathrm{a}<0$ dan $\mathrm{b}>0)$, sehingga panjang pada saat $50 \%$ tertangkap $\left(\mathrm{L}_{c}\right)$ sama dengan $-\mathrm{a} / \mathrm{b}$

Ukuran pertama kali matang gonad (Lm) ditentukan dengan melalui metode Spearman Karber. Dimana ikan yang memiliki TKG III dan IV dianggap sebagai ikanikan yang telah matang gonad (Oktaviyani et al., 2016). Penentuan Lm mengikuti rumus sebagai berikut :

$$
\mathrm{Lm}=\frac{[1-\mathrm{p}]}{\mathrm{p}}
$$

Keterangan:

$\mathrm{p}$ : proporsi matang gonad
Kemudian dilakukan regresi antara nilai tengah kelas dengan $\ln (1-\mathrm{p} / \mathrm{p})$ untuk mendapatkan nilai a dan b, dan dimasukan ke dalam rumus:

$$
\mathrm{Lm}_{50 \%}=\frac{\mathrm{a}}{\mathrm{r}}, \mathrm{r}-\mathrm{b}
$$

Keterangan :

$$
\begin{aligned}
& \mathrm{r}: \text { koefisien regresi } \\
& \mathrm{a}: \text { intercept } \\
& \mathrm{b}: \text { slope }
\end{aligned}
$$

Suhu suatu perairan dipengaruhi oleh musim, lintang, ketinggian dari permukaan laut, waktu dalam hari, sirkulasi udara, penutupan awan serta kedalaman perairan (Ali et al., 2013). Pengukuran suhu menggunakan thermometer dengan satuan pengukuran adalah ${ }^{\circ} \mathrm{C}$.

Kecerahan adalah sebagian cahaya yang diteruskan ke dalam air dan dinyatakan dengan persen (\%), dari beberapa panjang gelombang di daerah spektrum yang terlihat cahaya melalui lapisan sekitar satu meter Monalisa et al(2010), jatuh agak lurus pada permukaan air. Radiasi matahari sangat penting untuk metabolisme kehidupan ekosistem di perairan (Fatmawati, et al., 2016). Analisis pengukuran kecerahan menggunakan rumus :

$$
\mathrm{S}=\frac{\mathrm{d} 1+\mathrm{d} 2}{2}
$$

Keterangan:

$\mathrm{S}=$ Nilai kecerahan suatu perairan

d1 = Kedalaman pertama kali secchi disk tidak terlihat

d2 = Kedalaman pertama kali secchi disk terlihat

DO (oksigen terlarut) dibutuhkan oleh semua makhluk hidup untuk pernapasan, proses metabolisme atau pertukaran zat yang kemudian menghasilkan energi untuk pertumbuhan (Ali et al., 2013). Penurunan konsentrasi oksigen akan menurunkan kegiatan fisiologis makhluk hidup dalam air, seperti penurunan nafsu makan, pertumbuhan dan kecepatan berenang ikan (Susana, 2009). Pengukuram DO diukur dengan menggunakan DO teskit dan penilainnya menggunakan kertas indikator penilaian.

$\mathrm{pH}$ merupakan suatu ekspresi dari konsentrasi ion hidrogen $(\mathrm{H}+)$ di dalam air. Biasanya dinyatakan dalam minus logaritma dari konsentrasi ion $\mathrm{H}$. $\mathrm{pH}$ sangat penting sebagai parameter kualitas air, karena $\mathrm{pH}$ mengontrol tipe dan laju kecepatan reaksi beberapa bahan di dalam air (Susana, 2009). pH merupakan salah satu parameter yang dapat menentukan produktivitas suatu perairan. Setiap organisme membutuhkan 
derajat keasaman pH yang optimum bagi kehidupannya (Lensun dan Tumembouw, 2013).

Parameter $\mathrm{pH}$ diukur menggunakan kertas indikator universal ke dalam air sampel. Kemudian mencocokannya dengan warna kalibrasi yang ada pada tempatnya. Adapun kisaran pH untuk menyatakan derajat keasaman suatu perairan tersebut dalam kondisi asam, basa atau netral antara lain:

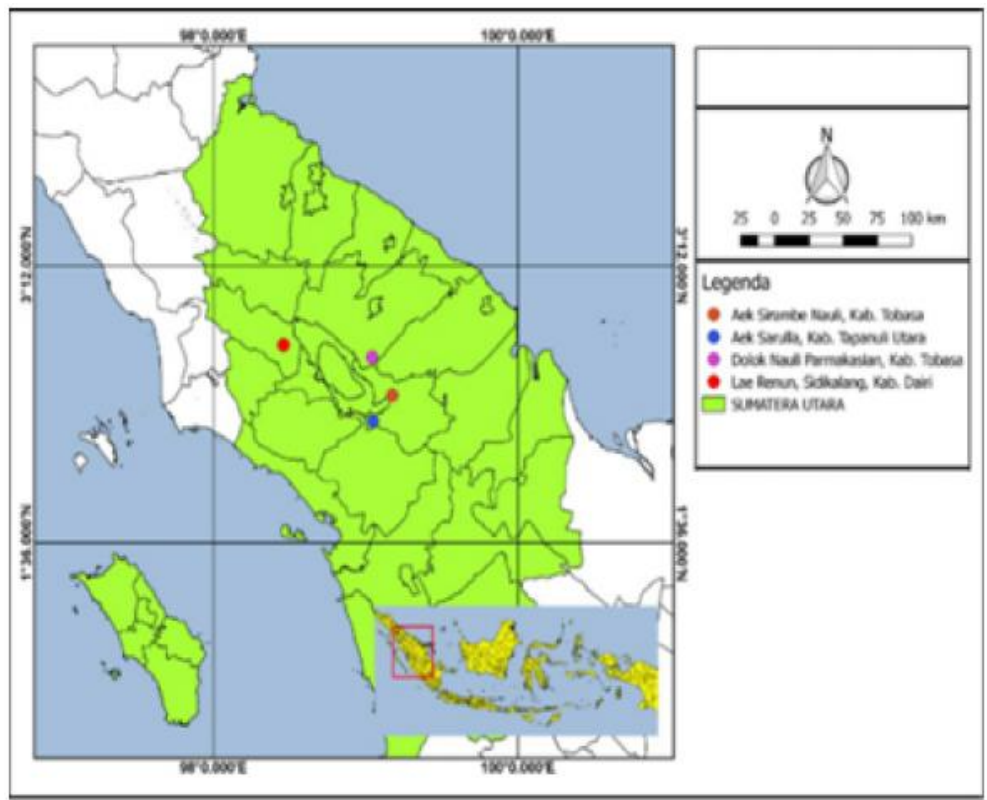

Gambar 1. Stasiun Pengamatan.

Figure 1. Observation Stations.

Tabel 1. Hubungan nilai pH dengan kondisi perairan

Table 1. Relationship between $\mathrm{pH}$ and water conditions

\begin{tabular}{cc}
\hline Nilai pH & Kondisi \\
\hline 7 & Normal \\
$0-<7$ & Asam \\
$>7-14$ & Basa \\
\hline
\end{tabular}

\section{HASIL DAN PEMBAHASAN}

Ikan batak (Neolissochilus thienemanni) yang di dapatkan dari penelitian sebanyak 38 ekor (25 ekor jantan dan 13 ekor betina) yang memiliki ukuran panjang tubuh $16-41.9 \mathrm{~cm}$ (rata-rata $28,93 \mathrm{~cm}$ ) dan berat tubuh berkisar antara 73 gram - 392 gram (ratarata 197 gram). Ikan batak memiliki 3 warna tubuh yang unik (hitam, putih dan keemasan), sedikit gelap dan memiliki 2 kumis dibawah mulut. Dari hasil pengamatan, ikan batak memiliki ciri morfologis : I jari- jari keras dan 6 jari- jari lunak pada sirip dada (P.I-6), I jari-jari keras dan 8 jari-jari lunak pada sirip perut (V.I-8), III jari-jari keras dan 6 jari-jari lunak pada sirip punggung (D III-6), I jari-jari keras dan 15 jarijari lunak pada sirip dubur (A I-15) dan 20 jari-jari lunak pada sirip ekor (C 20) dan memiliki 22 jumlah sisik pada bagian gurat sisi.

\section{Hubungan Panjang-Berat Ikan}

Berdasarkan analisi diperoleh persamaan hubungan panjang berat ikan batak sebagai berikut.

$$
\begin{array}{ll}
\text { Gabungan } & : \mathrm{W}=5,21127 \mathrm{~L}^{1,013} \\
\text { Jantan } & : \mathrm{W}=4,6465 \mathrm{~L}^{1,1039} \\
\text { Betina } & : \mathrm{W}=7,2193 \mathrm{~L}^{1,0109}
\end{array}
$$

Berdasarkan pengujian terhadap nilai b dengan $t-$ 


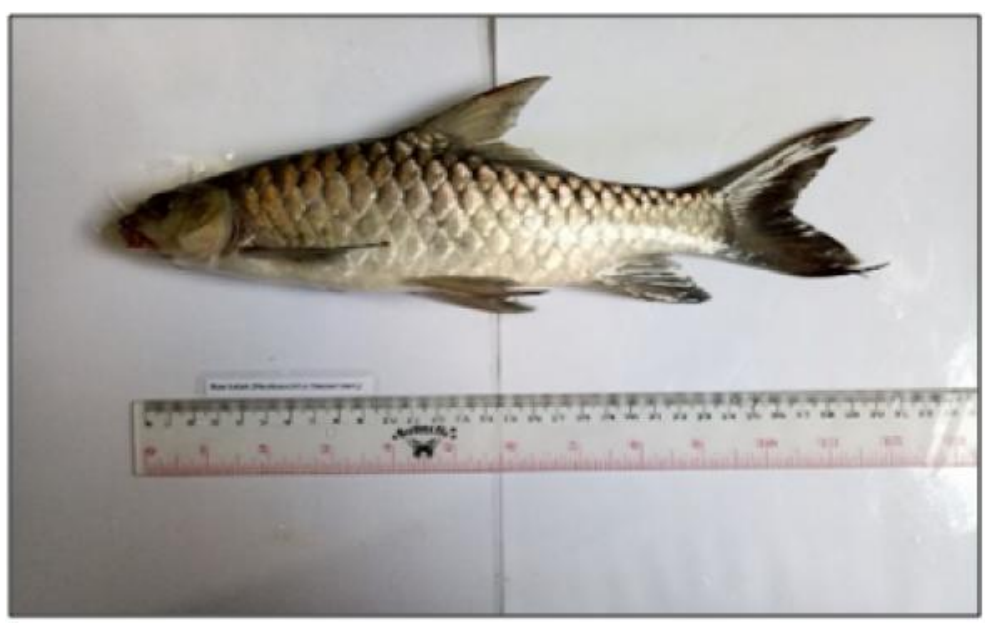

Gambar 2. Ikan batak hasil tangkapan.

Figure 2. Batak fish.

test, di dapatkan nilai $\mathrm{t}_{\text {hitung }}>\mathrm{t}_{\text {tabel }}$, untuk ketiga sumber data, sehingga kesimpulan yang didapat adalah pertumbuhan panjang-berat ikan batak bersifat allometrik negatif sehingga pertambahan Panjang lebih cepat jika dibandingkan dengan pertambahan berat ikan.Menurut Badrudin dan Wudianto (2004), manfaat dari informasi panjang berat antara lain adalah bahwa melalui persamaan matematik tersebut $\left(\mathrm{W}=\mathrm{aL}^{\mathrm{b}}\right)$ maka dapat memperkirakan berat ikan pada panjang tertentu dan sebaliknya. Pola pertumbuhan ikan jantan dan betina relatif tidak berbeda, dengan nilai $b$ yang relatif sama, yaitu 2,94 (jantan) dan 2,92(betina). Persamaan hubungan panjang berat ikan batak pada Gambar 3.

Pertumbuhan ikan batak yang bersifat allometrik negatifjuga didukung oleh hasil penelitian Barus et al (2014) di Sungai Asahan yang memperoleh nilai $\mathrm{W}=$ $\mathrm{aL}^{\mathrm{b}}\left(0.022 \mathrm{~L}^{2,998}\right)$, artinya bahwa pertumbuhan panjang lebih cepat dari pertambahan berat. Menurut
Rochmatin et al. (2014) menyatakan bahwa kecepatan pertumbuhan panjang dan berat ikan dapat dipengaruhi oleh faktor internal dan faktor eksternal. Faktor internal antara lain keturunan dan jenis kelamin yang membawa sifat genetik masing - masing dari alam yang sulit untuk dikontrol. Sedangkan faktor eksternal yang mempengaruhi pertumbuhan antara lain yaitu suhu, salinitas, makanan, dan pencemaran yang secara tidak langsung akan mengakibatkan menurunnya kualitas air.

\section{Nisbah Kelamin}

Jumlah ikan yang di dapatkan selama penelitian sebanyak 25 ekor jantan dan 13 ekor betina, sehingga nisbah kelamin ikan batak sebesar 1:0,52. Berdasarkan uji Chi-kuadrat yang dilakukan menunjukkan bahwa o diterima $\mathrm{H}_{1}$ di tolak $\left./ \mathrm{x}_{\text {hitung }}<\mathrm{x}_{\text {tabel }}\right)$. Hasil penelitian dari Saputra

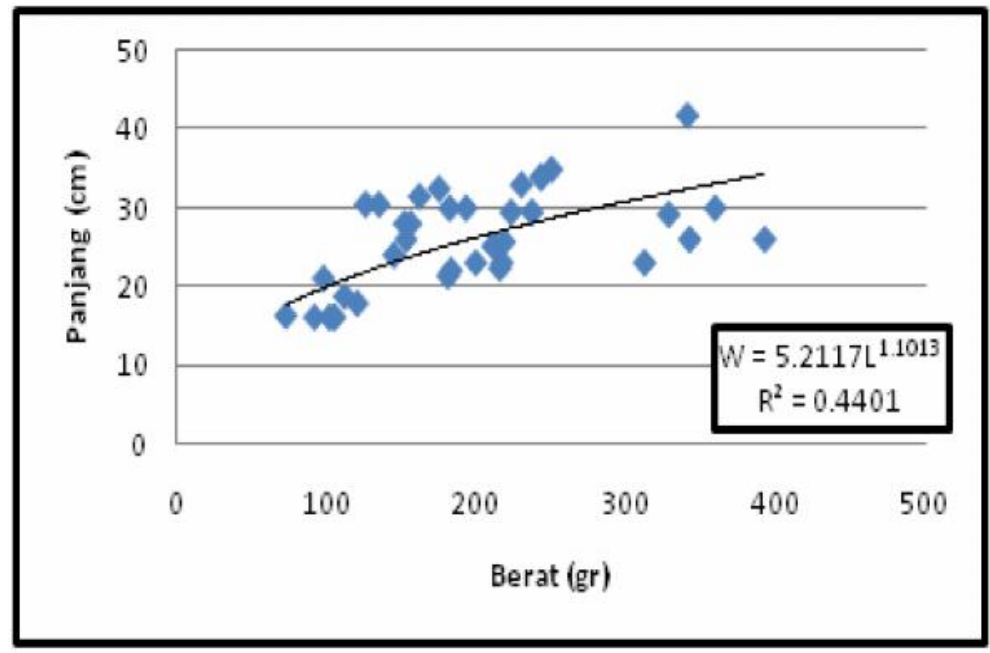

Gambar 3. Grafik Hubungan Panjang Berat Ikan Batak.

Figure 3. Graph of the Relationship of the Weight-Length of Batak Fish. 
et al., (2009) menyatakan bahwa rasio antara jantan dan betina memperoleh hasil 1:1,1 yang menunjukkan tidak adanya perbedaan antara jantan dan betina. Pengetahuan tentang keseimbangan jantan dan betina atau betina lebih banyak daripada jantan dapat diartikan bahwa populasi tersebut masih ideal untuk mempertahankan kelestarian.

Pengetahuan tentang rasio kelamin berkaitan dengan upaya mempertahankan kelestarian populasi ikan yang diteliti, maka diharapkan perbandingan ikan jantan dan betina seimbang. Keseimbangan perbandingan jumlah individu jantan dan betina mengakibatkan kemungkinan terjadinya pembuahan sel telur oleh spermatozoa hingga menjadi individuindividu baru semakin besar.

\section{Tingkat Kematangan Gonad}

Tingkat kematangan gonad oleh ikan batak selama penelitian(38 sampel) didapatkan rerata ikan tertangkap pada TKG III dan IV dengan persentase $42,11 \%$. Dari keseluruhan ikan yang didapatkan terdapat ikan yang belum matang gonad (TKG I dan II) dan ikan yang sudah matang gonad (TKG III dan IV). Adapun variasi tingkat kematangan gonad (TKG) pada ikan batak jantan dan betina dari mulai TKG I,II,III dan IV. Penentuan tingkat kematangan gonad dilakukan secara visual dari warna, bentuk dan ukuran gonad (Sutjipto et al., 2013). Dilihat dari tabel 2. Bahwa ikan batak yang tertangkap didominasi oleh TKG III.

\section{Ukuran Pertama Kali Tertangkap dan Ukuran Pertama Kali Matang Gonad}

Ukuran panjang rata-rata tertangkap merupakan hal yang penting untuk dipelajari karena dengan menghubungkan ukuran rata-rata tertangkap dengan ukuran pertama kali matang gonad maka dapat

Tabel 2. Tingkat Kematangan Gonad

Table 2. Gonad Maturity Rate

\begin{tabular}{|c|c|c|c|c|c|c|c|c|c|}
\hline \multirow{3}{*}{ Jenis Kelamin } & \multicolumn{9}{|c|}{ Tingkat Kematangan Gonad } \\
\hline & \multicolumn{2}{|c|}{ I } & \multicolumn{2}{|c|}{ II } & \multicolumn{2}{|c|}{ III } & \multicolumn{2}{|c|}{ IV } & \multirow{2}{*}{ 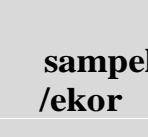 } \\
\hline & $\mathbf{n}$ & $\%$ & $\mathbf{n}$ & $\%$ & $\mathbf{n}$ & $\%$ & $\mathbf{n}$ & $\%$ & \\
\hline Jantan & 2 & 13.60 & 4 & 17.11 & 11 & 32.89 & 8 & 36.40 & 25 \\
\hline Betina & 2 & 17.99 & 1 & 31.65 & 5 & 19.66 & 5 & 25.66 & 13 \\
\hline Gabung & 4 & 10.53 & 5 & 13.16 & 16 & 42.11 & 13 & 34.21 & 38 \\
\hline
\end{tabular}

disimpulkan apakah sumberdaya tersebut merupakan sumberdaya yang lestari atau tidak, artinya dapat diketahui apakah pada ukuran tertangkap tersebut ikan tersebut telah mengalami pemijahan atau belum mengalami pemijahan. Berdasarkan hasil penelitian diperoleh ukuran panjang rata-rata ikan batak yang tertangkap dengan jala adalah sebagai berikut :

$\begin{array}{ll}\text { Jantan } & : 26,00 \mathrm{~cm} \\ \text { Betina } & : 25,04 \mathrm{~cm}\end{array}$

Berdasarkan hasil tersebut terlihat bahwa ikan jantan umumnya tertangkap pada ukuran yang lebih besar dari ikan betina. Ukuran pertama kali ikan matang gonad penting diketahui karena dengan mengetahui nilai Lm maka dapat digunakan untuk menyusun suatu konsep pengelolaan lingkungan perairan. Hasil penelitian tentang ukuran Pertama Kali Matang Gonad Ikan Batak sebagai berikut :

Jantan $\quad: 25,89 \mathrm{~cm}$
Betina $\quad: 23,29 \mathrm{~cm}$

Nilai Lm ikan batak jantan yang diperoleh ternyata lebih kecil daripada nilai Lc yang didapatkan $(25.89<$ 26.00) sedangkan nilai Lm ikan batak betina juga lebih kecil daripada nilai Lc $(23.29<25.04)$. dapat disimpulkan bahwa baik ikan batak jantan maupun ikan batak betina yang ditangkap ketika penelitian sudah matang gonad terlebih dahulu. Keberlanjutan perikanan tangkap sebaiknya didukung oleh peraturan yang menetapkan ukuran ikan yang layak tangkap. Salah satu kriteria ikan layak ditangkap yaitu memiliki panjang ikan pertama kali matang gonad lebih besar dari ukuran ikan pertama kali tertangkap (Jamal et al., 2011).

\section{Kebiasaan Makan}

Berdasarkan hasil pengamatan isi perut pada sampel ikan yang diamati, ikan batak tergolong dalam ikan omnivora (pemakan segala), terdapat beberapa jenis 
plankton dan hewan. Pengamatan ini sesuai dengan pernyataan (Sulastri et al., 1985; Haryono 1992 dalam Sinaga et al.,1999) tentang lambung ikan batak yang membulat seperti kantong dengan usus berbentuk gulungan dan panjang usus $2-3$ kali panjang tubuh. Hasil penelitian tentang kebiasaan makanan juga dilakukan oleh Barus et al (2014) di Sungai Asahan dimana sebagian besar ikan batak memakan berbagai jenis plankton.

\section{Aspek Perikanan}

Alat tangkap yang digunakan masyarakat dalam pengambilan ikan batak di sungai yaitu jala. Jala tebar atau jaring lempar (cast net) adalah jaring ikan yang berbentuk lingkaran kecil dengan pemberat pada

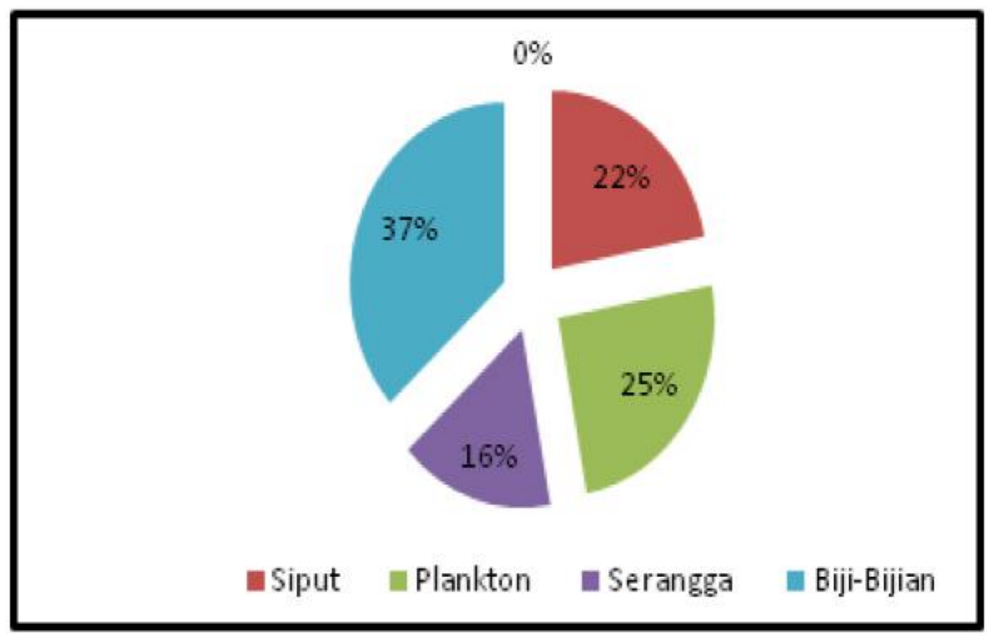

Gambar 4. Hasil identifikasi kebiasaan makan ikan batak.

Figure 4. Food habit of Batak fish.

setiap tepinya yang dilempar atau ditebar oleh nelayan sampai menyebar dipermukaan air dan tenggelam untuk menjerat ikan. Jala dibuat dari benang nilon dan memakai pemberat/timah dibawahnya dengan diameter 3 mdan mesh size 2 inch. Jala tebar dioperasikan 5-10 kali tebar bahkan lebih tergantung ikan yang tertangkap. Pada saat pengoperasian jala, jaring terjerat di bebatuan karena arus air yang deras berkisar pada $0,91-0,83 \mathrm{~m} / \mathrm{s}$. Hal ini juga dinyatakan oleh Adis et al (2017) bahwa sungai air deras yang sempit dan banyak bebatuan memiliki nilai kecepatan arus yang lebih tinggi dibandingkan dengan sungai air tenang.

\section{Parameter Kualitas Air}

Tabel 3. menunjukkan bahwa hasil uji parameter suhu, pH dan kecerahan masih berada pada standar

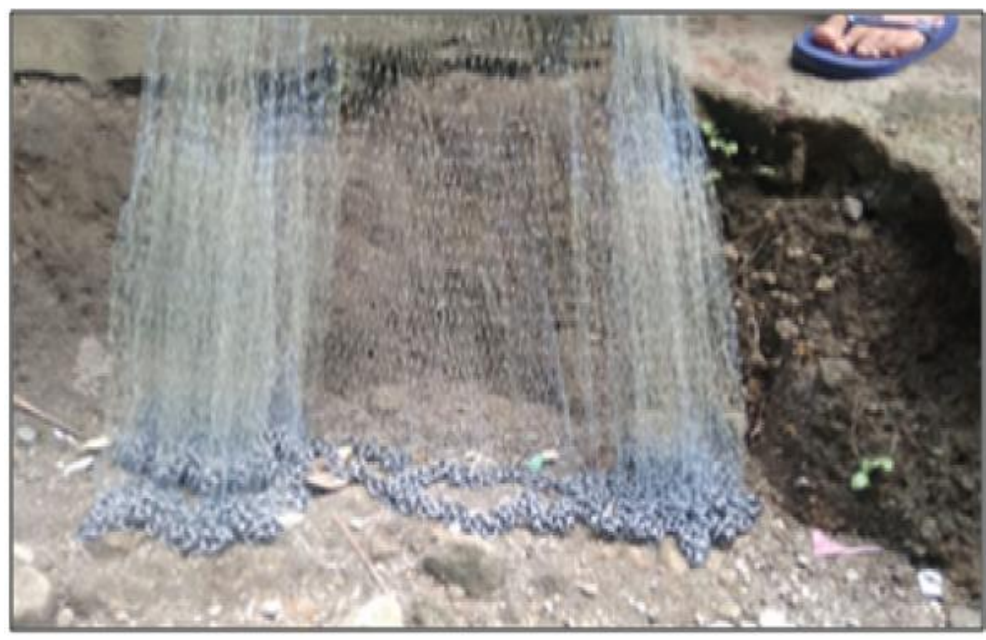

Gambar 5. Alat tangkap yang digunakan.

Figure 5. Fishing gear. 
baku mutu, sedangkan parameter DO berada diatas standar baku mutu. Hal ini dipengaruhi oleh kegiatan masyarakat yang menyebabkan penurunan kadar DO. Mahyudin et al (2015) menyebutkan bahwa standar baku mutu kualitas perairan berdasarkan Perda. Dari tabel diatas juga diperoleh nilai kecerahan sebesar 0.665 - $1 \mathrm{~m}$ yang dapat digunakan untuk kegiatan perikanan, dikarenakan standar baku mutu kegiatan perikanan $>3 \mathrm{~m}$ (Tarigan dan Edward, 2003).

Tabel 3. Pengukuran Kualitas Air di lokasi penelitian

Table 3. Water Quality Measurement in researh locations

\begin{tabular}{|c|c|c|c|c|c|}
\hline \multirow[t]{2}{*}{ No. } & \multirow[t]{2}{*}{ Nama Lokasi } & \multicolumn{4}{|c|}{ Parameter Kualitas Air } \\
\hline & & $\begin{array}{c}\text { Suhu } \\
\left({ }^{\circ} \mathbf{C}\right)\end{array}$ & pH & $\begin{array}{l}\text { Kecerahan } \\
(\mathbf{c m})\end{array}$ & DO (mg/l) \\
\hline 1 & Lae Renun & $19-23$ & $7-8$ & $63,5-66,5$ & $4-5$ \\
\hline 2 & Aek Sirambe & $20-25$ & $7-8$ & 63,5 & $4-5$ \\
\hline 3 & Aek Sarulla & $19-23$ & 7 & $65-1$ & 4- 5 \\
\hline StaI & $\begin{array}{l}\text { ku Mutu PP No. } 82 \\
\text { ahun } 2001\end{array}$ & - & $6-9$ & - & 3 \\
\hline
\end{tabular}

\section{Pengelolaan Ikan Batak (Neolissochilus thienemanni)}

Ikan batak (Neolissochilus thienemanni) digunakan sebagai makanan para raja (pada saat ini, ikan batak dimakan oleh pejabat daerah untuk pesta/ pertemuan) dan untuk upacara perkawinan sebagai sesembahan (upa - upa) kepada Tuhan yang diberikan oleh pihak isteri kepada pihak suami. Adapun orangtua memberikan hidangan ikan batak kepada anaknya yang ingin melanjutkan kuliah, dengan harapan Tuhan selalu memberikan kesehatan, keberhasilan dan diberkati disetiap langkahnya. Adapun kepercayaan yang timbul dikalangan masyarakat bahwa ikan ini tidak boleh ditangkap karena akan mendatangkan musibah. Kepercayaan masyarakat dalam hal ini masih sangat kental, akan tetapi ikan ini sudah sulit di dapat dan memiliki harga yang sangat mahal Rp, 300.000/ ekor. Oleh masyarakat setempat ikan batak tidak langsung dijual, melainkan di simpan sampai diadakannya penyelenggaraan upacara adat.

Pada tahun 2014, masyarakat pernah melakukan uji coba budidaya KJA di pinggiran Danau Toba. Namun, pola pertumbuhan ikan ini menjadi lambat karena KJA yang bersifat tenang bertolak belakang dengan habitat asli ikan ini. Dengan menurunnya jumlah populasi ikan batak (Neolissochilus thienemanni), maka Ikan ini termasuk dalam International Union for Conservation and Nature (IUCN) Red listyang terancam punah (Vulnerable).

Adanya introduksi ikan mas atau nila kedalam perairan maka semakin membuat keberadaan ikan batak terancam. Sebab ikan introduksi memberikan dampak buruk terhadap telur ikan batak dikarenakan ikan introduksi memakan telur-telur ikan batak sedangkan ikan batak hanya memijah dengan ikan batak setempat. Jika keadaan ini berlangsung lama, maka kelangkaan terhadap ikan batak semakin meningkat.

Melihat dari kepentingan ikan ini untuk masyarakat, maka perlu dilakukan pengelolaan/ rekayasa dari segi habitat demi menjaga populasi ikan batak untuk tetap lestari. Dengan memahami karakteristik ekobiologi ikan batak, maka dapat dilakukan upaya kegiatan konservasi ikan melalui penetapan sungai tertentu menjadi daerah habitat ikan yang didukung. Pembentukan Kelompok Mayarakat (Pokmasi) adalah salah satu cara yang efektif dalam melaksanakan proses pelestarian ikan batak, dengan tujuan bahwa masyarakat menjadi ujung tombak pelaksana pelestarian di lapangan, sementara pemerintah menjadi fasilitator, yang menyediakan penyuluhan, koordinasi serta dana untuk menunjang kegiatan konservasi. Salah satu nya dengan melakukan domestikasi. Domestikasi adalah salah satu upaya untuk mencegah terjadinya kepunahan terhadap populasi spesies yang terancam punah seperti ikan batak (Neolissochilus thienemanni) yang memiliki nilai adat tinggi untuk masyarakat Batak. Bentuk domestikasi yang bisa dilakukan yaitu lubuk larangan dekat aliran sungai yang deras sehingga ikan tetap mendapatkan suasana habitat asli nya. Kemudian pembuatan kolam beton dengan susunan batu mirip habitat asli serta aliran air deras yang berasal dari sungai tersebut. Demikian peraturan demi peraturan perlu ditetapkan untuk perlindungan ihan batak ini dan keberlanjutan kehidupan spesies ini (Jamal et al., 2011).

Selain itu, perlu dilakukan upaya pemijahan dan budidaya ikan batak mengingat ikan batak hanya akan memijah dengan ikan batak di habitat yang sama, 
dengan memanfaatkan Balai Benih Ikan (BBI) yang telah dibangun pemerintah daerah. Pemberian teknologi pembenihan ikan sudah biasa dilakukan dengan bantuan hormone HCG dan Ovaprim serta pemberian pakan komersial untuk pemijahan buatan dengan derajat penetasan yang tinggi guna mendapatkan benih ikan batak yang berkualitas dan jumlah yang memadai dengan tujuan memulihkan ikan batak di habitat aslinya.

Oleh karena sumberdaya ikan yang memiliki sifat akses terbuka, maka stok sumberdaya ikan akan menurun hingga titik terendah. Dalam rangka pengelolaan ikan batak yang dapat dimanfaatkan secara maksimal oleh warga sekitar dimasa sekarang dan dimasa yang akan datang, maka perlu adanya kegiatan patrol di PUD untuk pengawasan/pengecekan langsung oleh DKP Kabupaten terhadap kegiatan penangkapannnya serta menegakkan hukum bagi masyarakat yang melangggar ketentuan/regulasi daerah yang telah di tetapkan. Selain itu perlu adanya kegiatan sosialisasi bagi masyarakat mengenai keadaan sumberdaya ikan batak di alam seebagai langkah untuk meningkatkan kesadaran masyarakat agar ikut serta dalam mewujudkan pemanfaatan yang lestari dan berkelanjutan. Peran pemerintah maupun masyarakat sangat penting dikolaborasi dalam hal pengelolaan.

\section{KESIMPULAN}

Ikan batak (Neolissochilus thienemanni) yang tertangkap sebanyak 38 ekor (25 ekor jantan; 13 ekor betina) yang didapatkan di tiga kabupaten. Ikan ini ditangkap menggunakan jala (cash net) dengan diameter dan ukuran mata jaring/mesh size 2 inch.Distribusi frekuensi panjang ikan batak yang ditemukan berkisar antara 16-41.9 cm (rata-rata $28.93 \mathrm{~cm}$ ) dan berat antara 73 gram s.d 392 gram (rata-rata 197 gram). Hubungan panjang-berat ikan batak bersifat allometrik negatif (pertumbuhan panjang lebih cepat dari pertambahan bobot berat). Dengan nilai $\mathrm{Lm}<\mathrm{Lc}$ baik ikan batak jantan maupun betina $(25.89<26.00 ; 23.29<25.04)$ dapat disimpulkan bahwa baik ikan batak jantan maupun ikan batak betina yang ditangkap ketika penelitian sudah matang gonad terlebih dahulu. Hal ini terjadi karena ikan batak disuatu tempat hanya akan memijah pada ikan batak setempat yang mengakibatkan tingginya tingkat penurunan spesies dan rerata ikan batak lebih dominan memakan bijibijian sebanyak $37 \%$, plankton $25 \%$, siput $22 \%$ dan serangga sebanyak $16 \%$. Diperkirakan bahwa ikan batak banyak menkonsumsi biji-bijian dari pohon sekiar sungai dan memakan plankton yang ada di substrat bebatuan.

Pengujian kualitas air yang dilakukan menandakan bahwa sungai tersebut memiliki kriteria standar untuk habitat ikan batak. Namun, akibat penangkapan yang terlalu sering mengakibatkan ikan ini terancam punah dari habitatnya sendiri dan beberapa faktor lain seperti warung/rumah makan disekitar sungai dan ikan batak hanya bereproduksi dengan ikan batak di satu tempat saja. Sehingga sedikitnya kesempatan untuk berkembang biak. Untuk saat ini, belum adanya upaya pengelolaan baik dari pemerintah maupun pemuka masyarakat adat untuk melindungi ikan batak. Maka dari itu, perlunya diadakan upaya pemijahan dan budidaya ikan batak mengingat ikan batak hanya akan memijah dengan ikan batak di habitat yang sama, dengan memanfaatkan Balai Benih Ikan (BBI) yang telah dibangun pemerintah daerah. Pemberian teknologi pembenihan ikan sudah biasa dilakukan dengan bantuan hormone HCG dan Ovaprim serta pemberian pakan komersial untuk pemijahan buatan dengan derajat penetasan yang tinggi guna mendapatkan benih ikan batak yang berkualitas dan jumlah yang memadai dengan tujuan memulihkan ikan batak di habitat aslinya.

\section{UCAPAN TERIMA KASIH}

Ucapan terimakasih ditujukan kepada Dinas Kelautan Perikanan Provinsi Sumatera Utara, Dinas Kelautan Perikanan Kabupaten Toba Samosir, Dinas Kelautan Perikanan Kabupaten Tapanuli Utara, Dinas Kelautan Perikanan Kabupaten Dairi,

\section{DAFTAR PUSTAKA}

Adis, M. A., Setyawati, T. R., \& Yanti, A. H. (2017). Keragaman Jenis Ikan Arus Deras di Aliran Riam Banangar Kabupaten Landak, 3(2), 209-217.

Ali, A., Soemarno, \& Purnomo, M. (2013). Kajian Kualitas Air dan Status Mutu Air Sungai Metro di Kecamatan Sukun Malang. Jurnal Bumi Lestari, 13(2), 265-274.

Alianto. (2017). Analisis Peran dan Kontribusi Fitoplankton Laut Dalam Iklim Global, (September 2016).

Amri, K., Suman, A., \& Umar, C. (2009). Status Kawasan Konservasi Perikanan Perairan Umum Daratan Di Beberapa Lokasi Pulau Sumatera. Jurnal Bawal, 2(5), 199-208.

Badrudin dan Wudianto, 2004. Biologi habitat dan sebaran ikan layur serta beberapa aspek perikanannya. Diseminarkan pada Workshop Rencana Pengelolaan Perikanan Layur. Co Fish Project. 13 halaman.

Barus, T. A. (2016). Potensi Sumberdaya Perairan Daratan di Sumatera Utara dan Pengelolaannya (Studi Kasus/ : Danau Toba dan Sungai Asahan).

Barus, T. A., Wahyuningsih, H., Ginting, E. M., \& Simanjuntak, C. P. (2014). The Center of Excel- 
lency Ecobiological Review Of Neolissochilus sumatranus (Ikan Batak) (Weber and de Beaufort, 1916 ) In Asahan River, North Sumatera The Center of Excellency, 39-45.

Fatmawati, Salwiyah, \& Irawan, N. (2016). Produktivitas Primer Perifiton Di Perairan Air Terjun Tinonggoli (Nanga-nanga)Kota Kendari Sulawesi Tenggara. Jurnal Manajemen Sumberdaya Perairan, 2(1), 1-7.

Fiesca, E. D., Setyobudiandi, I., \& Krisanti, M. (2014). Kondisi Perairan Dan Struktur Komunitas Makrozoobentos Di Sungai Belumai Kabupaten Deli Serdang Provinsi Sumatera Utara. Water Quality Condition And Community Structure of Macrozoobenthos In Belumai River, Deli Serdang District, North Sumatra Province. Jurnal Depik, 3(April), 1-9.

Fithra, R. Y. (2010). Keanekaragaman Ikan Sungai Kampar Inventarisasi dari sungai Kampar Kanan, 2(4), 139-147.

Imelda, D. R., Chornelia, A., Mursyid, A., \& Kamsi, M. (2016). Short Communication/: Fish diversity of the Batang Toru River System, South Tapanuli, North Sumatra. Biodiversitas, Journal of Biological Diversity, 172), 634-641.

Kembaren, D. D., \& Ernawati, T. (2011). Beberapa Aspek Biologi Ikan Kuniran (Upeneus sulphureus) di Perairan Tegal dan Sekitarnya. Jurnal Bawal, 3(April), 261-267.

Kristanto, A. H., Asih, S., \& Winarlin. (2007). Karakterisasi Reproduksi Dan Morfometrik Ikan Batak dari Dua Lokasi (Sumatera Utara dan Jawa Barat), 2, 59-65.

Lensun, M., \& Tumembouw, S. (2013). Tingkat Pencemaran Air Sungai Tondano Di Kelurahan Ternate Baru Kota Manado. E-Journal Budidaya Perairan, 1(2), 43-48.

Mahyudin, Soemarno, \& Prayogo, T. B. (2015). Analisis Kualitas Air Dan Strategi Pengendalian Pencemaran Air Sungai Metro di Kota Kepanjen Kabupaten Malang, 6(2), 105-114.

Monalisa, S. S., \& Minggawati, I. (2010). Kualitas air yang mempengaruhi pertumbuhan ikan nila(oreochromis sp) di Kolam Beton dan Terpal, 5, 526-530. Retrieved from Kualitas air yang mempengaruhi pertumbuhan ikan nila(oreochromis sp) di Kolam Beton dan Terpal

Muliawan, I., Fahrudin, A., Fauzi, A., \& Boer, M. (2014). Analysis Of Stakeholders On Grouper Fisheries, Preliminary Study Toward Implementation Of Ecosystem Approach For Fisheries Management In Spermonde Islands Makassar, 233-246.

Muthmainnah, D., Dahlan, Z., Susanto, R. H., Gaffar, A. K., \& Priadi, D. P. (2012). Pola Pengelolaan Rawa
Lebak Berbasis Keterpaduan Ekologi-EkonomiSosial-Budaya untuk Pemanfaatan Berkelanjutan, 59-67.

Nasution, H. A., \& Sihombing, A. T. (2017). Analisis Kandungan Logam Berat Timbal $(\mathrm{Pb})$ dalam Air Sungai Silau di Kota Kisaran.

Nurudin, F. A., Kariada, N., \& Irsadi, A. (2013). Keanekaragaman Jenis Ikan di Sungai Sekonyer Taman Nasional Tanjung Puting Kalimantan Tengah, 2(2), 118-125.

Oktaviyani, S., Boer, M., \& Yonvitner. (2016). Biological Aspects Of Japanese Threadfin Bream ( Nemipterus japonicus, In The Gulf of Banten,8(April), 21-28.

Partomo, Mangkuprawira, S., S.Hubies, A. V., \& Adrianto, L. (2011). Pengelolaan Danau Berbasis Co-Management/ : Kasus Rawa Pening, 4(1), 106113.

Prihatiningsih, \& Turni Hartati, S. (2012). Biologi Reproduksi Dan Kebiasaan Makan Ikan Banggai Cardinal(Pterapogon kauderni, Koumans 1933) Di Perairan Banggai Kepulauan.JurnalBawal, 4(April), $1-8$.

Rochmatin, S. Y., Solichin, A., \& Saputra, S. W. (2014). Aspek Perumbuhan dan Reproduksi Ikan Nilem (Osteochilus hasselti) di Perairan Rawa Pening Kecamatan Tuntang Kabupaten Semarang, 3, 153159.

Sagala, Effendi P. (2012). Komparasi Indeks Keanekaragaman dan Indeks Saprobik Plankton untuk menilai Kualitas Perairan Danau Toba Provinsi Sumatera Utara.

Saputra, S. W., Soedarsono, P., \& Sulistyawati, G. A. (2009). Beberapa Aspek Biologi Ikan Kuniran (Upenus spp.) di Perairan Demak, 5(1), 1-6.

Simangunsong, P., Siagian, M., \& Simarmata, A. H. (2015). Study of Periphyton on Glass Substrates in Sago River Pekanbaru.

Simanjuntak, C. (2012). Keragaman Dan Distribusi Spasio-Temporal Iktiofauna Sungai Asahan Bagian Hulu Dan Anak Sungainya. Prosiding Seminar Nasional Ikan VII, 7, 43-60.

Sinaga, E. S., Pulungan, C. P., \& Elfizon, D. (1999). Length-Wieght Ang Lenght-Lenght Relationshipamong The Body Parts Of Batak Fish (Tor soro) From The Upostream Of The Aek Godang River, North Sumatera Province.

Suryandari, A., \& Krismono. 2011. Beberapa Aspek Biologi Ikan Manggabai (Glossogobius giuris), Jurnal Bawal 3(5), 329-336.

Susana, T. (2009). Tingkat Keasaman (pH) dan Oksigen Terlarut sebagai Indikator Kualitas Perairan Sekitar Muara Sungai Cisadane. Jurnal Teknologi Lingkungan, 5(2), 33-39. 
Sutjipto, Soemarmo, M. S., \& Marsoedi. (2013). Dinamika Populasi Ikan Kurisi (Nemipterus hexodon)dari Selat Madura, 18(September), 165171.

Suwelu, I. S. (2005). Spesies Ikan Langka dan Terancam Punah perlu Dilindungi Udang-undang, 2(3), 161168.

Tarigan, M. S., \& Edward. (2003). Kandungan Total Zat Padat Tersuspensi (Total Suspended Solid) di Perairan Raha, Sulawesi Tenggara, 73), 109-119.

Wargasasmita, S. (2002). Ikan Air Tawar Endemik Sumatera yang Terancam Punah. Jurnal Iktiologi
Indonesia, 2(2), 41-49.

Wargasasmita, S. (2005). Ancaman Invasif Ikan Asing terhadap Keanekaragaman Ikan Asli, 5(1989), 510.

Wiadnyana, N. N., \& Kamal, M. M. (2015). Pengelolaan Sumberdaya Perikanan Danau Laut Tawar Aceh Tengah.

Zairin, Handaya, S., \& Supriatna, I. (2005). Kualitas Sperma Ikan Batak (Tor soro) Hasil Kripreservasi Semen menggunakan Dimetilsulfoksida (DMSO) dan Gliserol 5, 10 dan 15 \%, 4(2), 145-151. 